\title{
Cross-cultural adaptation of the Leg Ulcer Measurement Tool for Brazil: nursing methodology research
}

\author{
Adaptação transcultural do Leg Ulcer Measurement Tool para o Brasil: pesquisa metodológica em enfermagem \\ Adaptación transcultural de la Leg Ulcer Measurement Tool para Brasil: investigación metodológica en enfermería
}

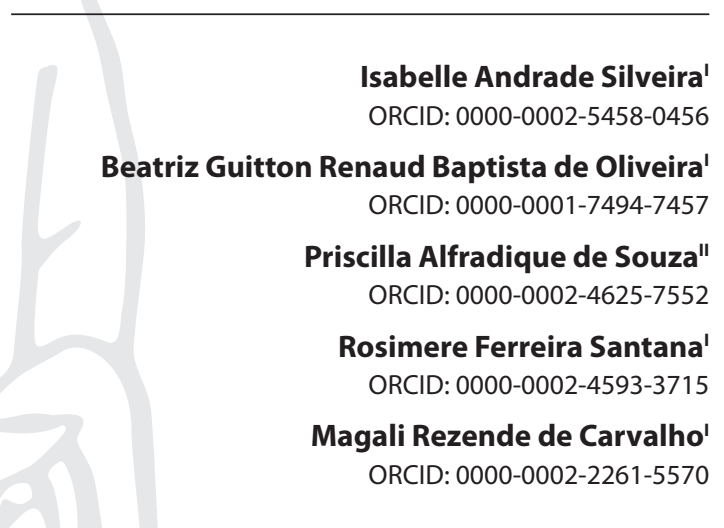

'Universidade Federal Fluminense. Niterói, Rio de Janeiro, Brazil. "Universidade Federal do Estado do Rio de Janeiro. Rio de Janeiro, Rio de Janeiro, Brazil.

How to cite this article: Silveira IA, Oliveira BGRB, Souza PA, Santana RF, Carvalho MR. Cross-cultural adaptation of the Leg Ulcer Measurement Tool for Brazil: nursing methodology research. Rev Bras Enferm. 2020;73(4):e20180944. doi: http://dx.doi.org/10.1590/0034-7167-2018-0944

Corresponding author:

Isabelle Andrade Silveira E-mail: isabelleandradesilveira@gmail.com

EDITOR IN CHIEF: Antonio José de Almeida Filho ASSOCIATE EDITOR: Rafael Silva

Submission: 02-17-2019

Approval: 08-02-2019

\begin{abstract}
Objectives: to translate and cross-culturally adapt the Leg Ulcer Measurement Tool to Brazilian Portuguese. Methods: methodological study involving the steps of initial translation, synthesis of translations, back-translation, expert panel and pretest. For analysis by the expert committee, the content validity index was calculated and in the pretest for practicality, the agreement rate was calculated. Satisfactory agreement was considered when $>0.8$ and $80 \%$, respectively. Results: the initial steps of translation were satisfactorily developed and there was little disagreement between the translators. In the expert panel, was obtained significant concordance of 0.97 . The pretest was performed with ten nurses and 30 patients. The feasibility of the translated version was evaluated with $100 \%$ agreement. Final Considerations: the instrument presented a high level of concordance among the experts during all steps and showed content validity thereby making the adaptation appropriate for the Brazilian context. Descriptors: Translation; Nursing Methodology Research; Validation Studies; Leg Ulcer; Nursing Evaluation.
\end{abstract}

\section{RESUMO}

Objetivos: traduzir e adaptar transculturalmente o Leg Ulcer Measurement Tool para a língua portuguesa do Brasil. Métodos: estudo metodológico envolvendo as etapas de tradução inicial, síntese das traduções, retrotradução, comitê de especialistas e pré-teste. Para análise do comitê de especialistas foi calculado o índice de validade de conteúdo e no pré- teste para a praticabilidade foi calculada a taxa de concordância. Considerou-se concordância satisfatória quando $>0,8$ e $80 \%$, respectivamente. Resultados: as etapas iniciais de tradução foram desenvolvidas satisfatoriamente e houve pouca discordância entre as tradutoras. No comitê de especialistas, a concordância obtida foi significativa $(0,97)$. O pré-teste foi realizado com 10 enfermeiros e 30 pacientes. Foi avaliada a praticabilidade da versão traduzida com concordância de $100 \%$. Considerações Finais: o instrumento apresentou alto nível de concordância entre os especialistas durante todas as etapas e demonstrou validade de conteúdo, tornando a adaptação adequada para o contexto brasileiro.

Descritores: Tradução; Pesquisa Metodológica em Enfermagem; Estudos de Validação; Úlcera da Perna; Avaliação em Enfermagem.

\section{RESUMEN}

Objetivos: traducir y adaptar interculturalmente La Leg Ulcer Measurement Tool al portugués brasileño. Métodos: investigación metodológica que incluyó los pasos de la traducción inicial, la síntesis de las traducciones, la traducción inversa, el comité de expertos y la prueba previa. Para el análisis del comité de expertos, se calculó el índice de validez de contenido y, en la prueba preliminar de practicidad, se calculó la tasa de acuerdo. Se consideró un acuerdo satisfactorio cuando $>0,8$ y $80 \%$, respectivamente. Resultados: las etapas iniciales de la traducción se desarrollaron satisfactoriamente y hubo poco desacuerdo entre las traductoras. En el comité de expertos, fue alcanzada concordancia significativa de 0,97. EI pretest se realizó con diez enfermeras y 30 pacientes. La viabilidad de la versión traducida se evaluó con el $100 \%$ de acuerdo. Consideraciones Finales: la herramienta para la evaluación de pacientes con úlceras en las piernas presentó una alta tasa de concordancia entre los especialistas durante todas las etapas y demostró la validez del contenido, lo que hace que la adaptación sea adecuada para el contexto brasileño.

Descriptores: Traducción; Investigación Metodológica en Enfermería; Estudios de Validación; Úlcera en la Pierna; Evaluación en Enfermería. 


\section{INTRODUCTION}

Leg ulcers stand out among chronic wounds of worldwide importance and affect 1 to $2 \%$ of the population around the world ${ }^{(1)}$. Individuals with leg ulcers have more health demands, lose more work days, require more health care at home and visit the emergency department and outpatient clinic more times than demographically comparable individuals in a population ${ }^{(2-3)}$.

Regarding etiology, ulcers can be classified as vascular (venous, arterial or mixed) and diabetic ulcers. According to the literature, 70 to $90 \%$ of leg ulcers are of venous origin and the remainder (30\%) are divided between arterial, mixed, diabetic and other ulcers (trauma, lymphatic and/or hematological problems) ${ }^{(4-6)}$.

Venous ulcers are wounds resulting from inadequate venous return related to chronic venous insufficiency, venous valvular anomalies and venous thrombosis ${ }^{(7-8)}$. Diabetic ulcers occur from peripheral neuropathies, are one of the main complications of this morbidity ${ }^{(9)}$ and by their complex pathophysiology, are notoriously difficult to heal ${ }^{(10)}$. Arterial ulcers occur because of interruption of flow and can lead to amputations due to insufficient arterial supply. They are more common in fingers and toes ${ }^{(11)}$.

In the future, the management of chronic wounds will become a health problem, since an important part of it involves periodic evaluation and documentation of healing ${ }^{(10)}$. At times, ulcers have been evaluated unsystematically and inappropriately ${ }^{(12)}$.

Hence the importance of using evaluation instruments that offer parameters and enable the ideal conduct for each stage of the healing process. The instruments define a common language and standardize the evaluation and documentation of wound characteristics. They can also be used to measure results in clinical trials and audits and facilitate comparison and grouping of results ${ }^{(10,13-14)}$.

The most widely used instrument for wound evaluation is the PUSH scale that was originally developed for pressure injuries. However, studies have already shown it is not valid for leg ulcers, mainly venous ulcers, which correspond to $80-90 \%$ of ulcers in this location $^{(13,15)}$. Considering these aspects and the lack of a specific instrument for leg ulcer evaluation in Brazil, was conducted a study of international search and analysis of ten instruments addressing clinical evaluation parameters ${ }^{(16)}$. The Leg Ulcer Measurement Tool (LUMT) stood out among these instruments. It was developed in Canada in 2004 and is indicated for the evaluation of different etiologies of leg ulcers. The LUMT instrument is quite complete, includes items of clinical assessment, pain and quality of life and instructions for its correct completion. In addition, its authors have performed the content and clinical validation process of the LUMT ${ }^{(17)}$.

The instrument contains a clinical assessment scale and instructions for its correct completion. The scale has two parts, namely: A-clinically evaluated domains, and $B$ - domains evaluated by the patient (representative). In part A, 14 items concern the evaluation of clinical characteristics of the ulcer; in part $B$, three items are related to the ulcer-related assessment of pain and quality of life. Each item (part A and B) contains five categories of ordered responses scored from 0 to 4 . In part $A$, as assessed by the health professional, the score ranges from 0 to 56 , and the higher the score the worse the stage of ulcer healing. In part B, evaluated by patients, the score ranges from 0 to 12 , and the higher the score the worse the pain and the quality of life.
For the use of LUMT in Brazil, was performed the cross-cultural translation and adaptation process for its adaption to the population and cultural characteristics of Brazil.

\section{OBJECTIVES}

To translate and transculturally adapt the Leg Ulcer Measurement Tool to Brazilian Portuguese.

\section{METHODS}

\section{Research ethical aspects}

This study was approved by the Research Ethics Committee of the Faculty of Medicine of the Universidade Federal Fluminense under number 1.585.542, CAAE number 56252216.2.0000.5243.

\section{Type of study}

This is a methodological study based on the methodology of Guillemin, Bombardier and Beaton of $1993^{(18)}$. It included five stages, namely: translation, synthesis of translations, back-translation, panel of experts and the pretest. The original published work is composed of two parts, the clinical assessment scale for patients with leg ulcers and the instructions for filling out the instrument. After the authors authorization, the instrument was cross-culturally adapted.

\section{Collection and organization of data}

The stages of initial translation, synthesis of translations and backtranslations occurred between March and June 2016. The content validation step through the panel of experts occurred in July 2016. The pretest was performed between August and September 2016.

\section{Translation and back-translation steps}

In the first stage, the original version of LUMT and its instructions were translated into Portuguese by two bilingual translators fluent in English and whose mother tongue was Brazilian Portuguese. Translations were done independently and as recommended, one of the translators had technical knowledge about the subject of the instrument (as a health professional), and the other did not have technical knowledge about the instrument.

In the second stage, after translations, the versions were compared, eventual discrepancies were resolved in a meeting with the two translators and the researchers of the study, and a consensual version was obtained. In the third stage, this consensual version in Portuguese was back-translated into English by two independent, foreign translators with fluency in Portuguese and knowledge of Brazilian culture, who did not participate in the initial translation and did not have access to the original published version of the LUMT. Translators were not informed about the purpose of the study and the original instrument and were not from the health area.

\section{Analysis by the Expert Panel}

In the fourth stage, the panel was grouped for consolidation of the consensual version and the other translated versions and development 
of the pre-final version for field tests. A group of 13 nurses that met at least two of the following criteria was formed:minimum experience of three years in teaching or practice in the area of wounds; Portuguese and English mastery; knowledge of the research methodology; and previous participation in research involving instrument validation. The selection of experts occurred by means of non-probabilistic and intentional sampling, and the invitation to participate was sent by email. This step involved the experts' technical review and evaluation of the instrument for validation of each item translated.

In this stage, the data collection instruments included a form for characterization of the expert (with name, age, training time, professional training and experience). There was also a file with all translated versions containing a Likert type scale: 1-totally disagree, 2-partially disagree, 3-partially agree, 4-fully agree, and space for observations for each item of the instrument.

\section{Pretest}

The fifth and final step was the pretest to assess if the translated and approved version by the expert panel was applicable in clinical practice. The LUMT was applied to individuals with leg ulcers by nurses of the Wound Healing Outpatient Clinic of the university hospital in the municipality of Niterói/RJ. The consecutive sample consisted of 30 patients with leg ulcers ${ }^{(18)}$.

In addition to the LUMT, nurses received a characterization form (name, age, sex, type of ulcer and time of wound), a form of professional characterization, and the modified feasibility assessment instrument ${ }^{(19)}$. This instrument contains four items that assess the ease of understanding of instructions, the items, the completion of answers and the interest in having a tool for assessing leg ulcers in clinical practice. The questions are assessed through a five-point Likert response scale, and the higher the percentage of "partially agree" and "totally agree" responses, the greater the feasibility of the instrument.

\section{Data analysis}

Data were collected and organized in a Microsoft Excel electronic database. Descriptive statistics were used for the characterization of experts. For the analysis by the panel of experts, was calculated the content validity index (CVI) of each translated item. In the CVI, is used a 0-4 points Likert scale (number of responses 3 or $4 /$ total number of responses). In order to check the validity, is considered the minimum concordance of $0.80^{(20)}$. For the feasibility analysis, was calculated the concordance rate (CR), which is expressed as percentage (number of specialists who agreed upon the item/number of specialists $\times 100$ ). The acceptable minimum concordance rate considered is of $80 \%(20)$.

\section{RESULTS}

\section{Initial translations and synthesis of translations}

After the two initial translations, T1 and T2 versions were compared and discrepancies were analyzed. The term chosen was the most adequate from a semantic and idiomatic point of view and defined consensually. The translators reported the main translation difficulty was the term "undermining". In consensus, it was defined that within the context of wound assessment, the correct translation is descolamento.

\section{Back-translations}

The synthesis version of the consensual meeting was backtranslated into English. The differences between the original instrument were few and in general, words that expressed the same meaning/had the same sense without compromising the original instrument. In the back-translation of instructions, the word "escasso" was back-translated by one translator as "scant" and by the other as "thick". "Scant" means escasso and "thick" means denso. The word "sem aderência" was back-translated by one translator as "not attached" and by another as "non-adherent". Not attached means não anexado and "non-adherent", não aderido. However, in both items, at least one of the translators translated the term with the same word as the original instrument (scant and not attached).

\section{Panel of Experts}

In the expert panel, after translation, synthesis of translations and back-translation, were grouped 13 nurses, of which 12 (92.3\%) were female, ten (77\%) were aged between 20 and 40 years, 11 (85\%) had up to 20 years of training. The majority, 12 (92.30\%), had specialization courses and masters and/or doctorate degrees and experience in wounds. The calculations for the evaluation of the translated scale reached 0.97 of CVI. Regarding the instructions for filling out the LUMT, all items presented CVI of 1.00. However, were suggested changes in some terms for better adaptation to the Brazilian reality, as described in Chart 1.

The approval of suggestions occurred when $70 \%$ of the panel of experts agreed with the proposal or proposed it, and changes were incorporated into the final version to achieve the best understanding of the instrument and equivalence with the Brazilian culture. Following the steps of translation, synthesis of translations, back-translation and expert panel, was obtained the LUMT version, as shown in Chart 2.

After the aforementioned steps of translation and adaptation, was obtained the Portuguese version of the instructions for filling out the LUMT, as demonstrated in Chart 3.

The pretest was performed at the outpatient clinic of the university hospital with ten nurses, out of which nine (90\%) were female, aged between 20 and 40 years, and up to 20 years of training. All of them had specialization courses and eight (80\%) had masters and/or doctorate degrees in the area of wounds.

At this point, the instrument was applied to 30 patients with leg ulcers. The difference between men and women was small, 16 (53.3\%) were male and 14 (46.7\%) were female. Most patients were elderly, 22 (73.3\%) aged between 61 and 90 years. In relation to underlying diseases, the predominance was of systemic arterial hypertension ( $\mathrm{SAH}$ ) and chronic venous insufficiency (CVI), present in ten patients (33.3\%). Regarding the etiology, 19 (63.3\%) of the patients presented venous ulcers located in a malleolar region. Regarding the time of ulcer, 22 (73.3\%) patients had wounds from between zero and ten years. Most patients, 20 (66.7\%), did not have a relapse and had a history of ulcers that had never healed. 
Chart 1 - Experts'suggestions for cross-cultural adaptation of the Leg Ulcer Measurement Tool, Niterói, Rio de Janeiro, Brazil, 2018

\begin{tabular}{|c|c|c|}
\hline Synthesis version & $\begin{array}{c}\text { Number of } \\
\text { experts who } \\
\text { suggested change }\end{array}$ & $\begin{array}{l}\text { Suggestions } \\
\text { of the panel of } \\
\text { experts }\end{array}$ \\
\hline $\begin{array}{l}\text { Domains assessed by } \\
\text { clinician }\end{array}$ & 12 (92.3\%) & $\begin{array}{c}\text { Clinically evaluated } \\
\text { domains }\end{array}$ \\
\hline Serosanguineous & $12(92.3 \%)$ & Serous and bloody \\
\hline Probes to bone & 12 (92.3\%) & Bone exposure \\
\hline Amount of pain & $12(92.3 \%)$ & Intensity of pain \\
\hline Delighted & 12 (92.3\%) & Very satisfied \\
\hline Overwhelming & 12 (92.3\%) & Saturated \\
\hline $\begin{array}{l}\text { Overwhelming/overcoming } \\
\text { the dressing system }\end{array}$ & 12 (92.3\%) & $\begin{array}{l}\text { Exceeding dressing } \\
\text { saturation limit }\end{array}$ \\
\hline Copious & $11(85 \%)$ & Large \\
\hline Attached & $11(85 \%)$ & Adherent \\
\hline Nonattached & 11 (85\%) & Non-adherent \\
\hline Dark pink & 10 (77\%) & Opaque/dark red \\
\hline Lightly colonized & 10 (77\%) & Poorly colonized \\
\hline $\begin{array}{l}\text { Rayon-tipped sterile applicator } \\
\text { or a wound probe }\end{array}$ & $10(77 \%)$ & $\begin{array}{l}\text { Evaluation } \\
\text { instrument }\end{array}$ \\
\hline Serous & 10 (77\%) & Glossy \\
\hline Terrible & $9(70 \%)$ & Awful \\
\hline
\end{tabular}

Chart 2 - Portuguese version of the Leg Ulcer Measurement Tool obtained after the expert panel. Niterói, Rio de Janeiro, Brazil, 2018

\begin{tabular}{|c|c|}
\hline \multicolumn{2}{|c|}{ LEG ULCER MEASUREMENT TOOL (LUMT) } \\
\hline Item/Domain & Response Categories \\
\hline \multicolumn{2}{|c|}{ (A) Clinician rated domains } \\
\hline A1. Exudate type & $\begin{array}{l}0 \text { None } \\
1 \text { Serosanguinous } \\
2 \text { Serous } \\
3 \text { Seropurulent } \\
4 \text { Purulent }\end{array}$ \\
\hline A2. Exudate amount & $\begin{array}{l}0 \text { None } \\
1 \text { Scant } \\
2 \text { Small } \\
3 \text { Moderate } \\
4 \text { Copious }\end{array}$ \\
\hline $\begin{array}{l}\text { A3. Size (from edge of } \\
\text { advancing border of } \\
\text { epithelium) }\end{array}$ & $\begin{array}{l}\text { (Length } x \text { Width) } \\
\text { 0 Healed } \\
1<2.5 \mathrm{~cm}^{2} \\
22.5-5.0 \mathrm{~cm}^{2} \\
35.1-10.0 \mathrm{~cm}^{2} \\
410.1 \mathrm{~cm}^{2} \text { or more }\end{array}$ \\
\hline A4. Depth & $\begin{array}{l}\text { Tissue Layers } \\
0 \text { Healed } \\
1 \text { Partial thickness skin loss } \\
2 \text { Full thickness } \\
3 \text { Tendon/joint capsule visible } \\
4 \text { Probes to bone }\end{array}$ \\
\hline
\end{tabular}

To be continued
Chart 2 (concluded)

\begin{tabular}{|c|c|}
\hline \multicolumn{2}{|c|}{ LEG ULCER MEASUREMENT TOOL (LUMT) } \\
\hline Item/Domain & Response Categories \\
\hline A5. Undermining & $\begin{array}{l}\text { Greatest at__ o'clock } \\
00 \mathrm{~cm} \\
1>0-0.4 \mathrm{~cm} \\
2>0.4-0.9 \mathrm{~cm} \\
3>0.9-1.4 \mathrm{~cm} \\
4>1.5 \mathrm{~cm}\end{array}$ \\
\hline A6. Necrotic tissue type & $\begin{array}{l}0 \text { None } \\
1 \text { Loose white to yellow slough } \\
2 \text { Attached white to yellow slough } \\
\text { or fibrin } \\
3 \text { Soft grey to black eschar } \\
4 \text { Hard dry Black eschar }\end{array}$ \\
\hline A7. Necrotic tissue amount & $\begin{array}{l}0 \text { None visible } \\
11 \text { to } 25 \% \text { of wound bed covered } \\
226 \text { to } 50 \% \text { of wound bed covered } \\
351 \text { to } 75 \% \text { of wound bed covered } \\
476 \text { to } 100 \% \text { of wound bed covered }\end{array}$ \\
\hline A8. Granulation tissue type & $\begin{array}{l}0 \text { Healed } \\
1 \text { Bright beefy red } \\
2 \text { Dusky pink } \\
3 \text { Pale } \\
4 \text { Absent }\end{array}$ \\
\hline $\begin{array}{l}\text { A9. Granulation tissue } \\
\text { amount }\end{array}$ & $\begin{array}{l}0 \text { Healed } \\
176 \text { to } 100 \% \text { of wound bed covered } \\
251 \text { to } 75 \% \text { of wound bed covered } \\
326 \text { to } 50 \% \text { of wound bed covered } \\
41 \text { to } 25 \% \text { of wound bed covered }\end{array}$ \\
\hline A10. Edges & $\begin{array}{l}0 \text { Healed } \\
1 \geq 50 \% \text { advancing border of } \\
\text { epithelium or indistinct borders } \\
2<50 \% \text { advancing border of } \\
\text { epithelium } \\
3 \text { Attached, no advancing border of } \\
\text { epithelium } \\
4 \text { Unattached or undermined }\end{array}$ \\
\hline $\begin{array}{l}\text { A11. Periulcerskin viability } \\
\text { - Callus } \\
\text { - Dermatitis(pale) } \\
\text { - Maceration } \\
\text { - Induration } \\
\text { - Erythema (bright red) } \\
\text { - Purple blanchable } \\
\text { - Purple non-blanchable } \\
\text { - Skin dehydration }\end{array}$ & $\begin{array}{l}\text { Number of factors affected } \\
0 \text { None } \\
1 \text { One only } \\
2 \text { Two or three } \\
3 \text { Four or five } \\
4 \text { Six or more factors }\end{array}$ \\
\hline A12. Leg edema type & $\begin{array}{l}0 \text { None } \\
1 \text { Non-pitting or firmness } \\
2 \text { Pitting } \\
3 \text { Fibrosis or lipodermatosclerosis } \\
4 \text { Indurated }\end{array}$ \\
\hline A13. Leg edema location & $\begin{array}{l}0 \text { None } \\
1 \text { Localized periulcer } \\
2 \text { Foot, including ankle } \\
3 \text { To mid-calf } \\
4 \text { To knee }\end{array}$ \\
\hline $\begin{array}{l}\text { A14. Assessment of } \\
\text { bioburden }\end{array}$ & $\begin{array}{l}0 \text { Healed } \\
1 \text { Lightly colonized } \\
2 \text { Heavily colonized } \\
3 \text { Localized infection } \\
4 \text { Systemic infection }\end{array}$ \\
\hline
\end{tabular}

To be continued 


\begin{tabular}{|c|c|}
\hline \multicolumn{2}{|c|}{ LEG ULCER MEASUREMENT TOOL (LUMT) } \\
\hline Item/Domain & Response Categories \\
\hline \multicolumn{2}{|c|}{ B) Patient (proxy) rated domains } \\
\hline $\begin{array}{l}\text { Pa B1. Pain amount (as it } \\
\text { relates to the leg ulcer). Rate } \\
\text { your pain, experienced in the } \\
\text { last } 24 \text { hours, on a scale from } \\
0 \text { to } 10, \text { where } 0 \text { is "no pain" } \\
\text { and } 10 \text { is the "worst pain". }\end{array}$ & $\begin{array}{l}\text { Numerical rating scale } \\
(0-10) \\
0 \text { None } \\
1>0-2 \\
2>2-4 \\
3>4-7 \\
4>7\end{array}$ \\
\hline $\begin{array}{l}\text { B2. Pain frequency (as it relates } \\
\text { to the leg ulcer). "Which of the } \\
\text { following terms best describes } \\
\text { how often you have had pain } \\
\text { in the last } 24 \text { hours?" }\end{array}$ & $\begin{array}{l}0 \text { None } \\
1 \text { Occasional } \\
2 \text { Position dependent } \\
3 \text { Constant } \\
4 \text { Disturbs sleep }\end{array}$ \\
\hline $\begin{array}{l}\text { B3. Quality of life (as it relates } \\
\text { to the leg ulcer)."How do you } \\
\text { feel about the quality of your } \\
\text { life at the present time?" }\end{array}$ & $\begin{array}{l}0 \text { Delighted } \\
1 \text { Satisfied } \\
2 \text { Mixed } \\
3 \text { Dissatisfied } \\
4 \text { Terrible }\end{array}$ \\
\hline \multicolumn{2}{|c|}{ Total (B) Patient (proxy) rated domains: } \\
\hline Proxy completed by: & \\
\hline
\end{tabular}

Chart 3 - Portuguese version of instructions the Leg Ulcer Measurement Tool obtained after the expert panel, Niterói, Rio de Janeiro, Brazil, 2018

\begin{tabular}{|l|}
\hline \multicolumn{1}{|c|}{ GENERAL INSTRUCTIONS } \\
\hline SEÇÃO A - Domínios avaliados clinicamente \\
As avaliações devem ser feitas pré-desbridamento, mas após a limpeza \\
da ferida. Os avaliadores devem observar o tipo e a quantidade de \\
exsudato ao remover os curativos. Sempre que possível, o intervalo desde \\
a última troca de curativo deve ser regular de uma avaliação para a \\
próxima.
\end{tabular}

A1. Exudate type-Reminder: Some wound care products may change the appearance of the exudate, eg, silver sulfadiazine or hydrocolloids. Definitions:

1 Serosanguineous - thin, watery, pale red to pink

2 Serous - thin, watery, clear, pale yellowish

3 Seropurulent-thin, opaque

4 Purulent-thick, opaque, yellow to green with foul odour (as distinct from body or foot odour)

A2. Exudate amount-Reminder: Consider time since last dressing change.

0 None-ulcer healed or wound tissue dry (if wound dressings

changes are not regular)

1 Scant-wound bed moist with dressing dry

2 Small—wound bed moist with some drainage on dressing

3 Moderate-obvious fluid in wound bed and $>50 \%$ of dressing

soaked

4 Copious-overwhelming the dressing system

A3. Size-Measure length as the longest diameter; width is perpendicular to length. Avoid diagonals. Calculate wound area as length by width. Write this in space provided and select appropriate response category.
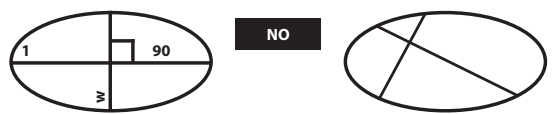

Chart 3 (concluded)

\section{GENERAL INSTRUCTIONS}

A4. Depth—layers. Pick the most appropriate descriptor.

A5. Undermining-Place moistened rayon-tipped sterile applicator or wound probe under the edge of the wound. Advance it gently as far as it will go. Place gloved thumb on the applicator against the wound edge to mark the extent of undermining on the applicator. Holding the thumb in place, remove the applicator and measure the distance along the applicator in centimetres. Indicate the area of greatest undermining according to the face of a clock, with 12 o'clock at the top of the patient.

A6. Necrotic tissue type-Reminder: The wound should be thoroughly cleansed before evaluating. Pick the predominant type of necrotic tissue, eg, if most of the wound bed is attached fibrin with small amount of black eschar, choose attached fibrin as tissue type.

A7. Necrotic tissue amount of predominant type selected in A6. The sum of the percentages in A7 and A9 may be less than but should not exceed $100 \%$

A8. Granulation tissue type-Choose predominant type of granulation tissue.

A9. Granulation tissue amount-(The sum of the percentages in A7 and A9 may be less than but should not exceed $100 \%$.) The percentage of granulation tissue refers only to the non epithelialized (open) portion of the wound. The advancing border of epithelium is not considered part of the wound surface.

A10. Edges—Definition: Indistinct borders—where you would not be able to trace the wound edge.

1- More than half of advancing borders may be indistinct because most of wound is epithelializing.

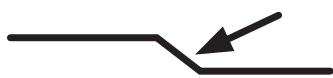

2- Less than half of the wound edge is advancing (the process of epidermal resurfacing appears smooth and shiny).

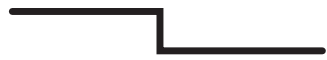

3- Attached, no advancing border-unable to probe.

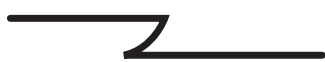

4- Unattached wound edge is undermined

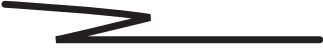

A11. Periulcer skin viability - Select the following items that are present; count the number selected; then use this total to determine appropriate response category. Definitions:

Callus-thick, dry epidermis

Scaling dermatitis-scaling, red skin which may be weeping Maceration - wet, white, opaque skin

Induration-feels firmer than surrounding skin when pressed Erythema-skin redness (bright red)

A12. Leg edema type-Indicate the worst edema type located anywhere on leg. Definition: lipodermatosclerosis-waxy, white, firm tissue.

A13. Leg edema location-Indicate the most proximal location of any type of edema. Clinical example: pitting edema ankles with nonpitting edema to mid-calf: For A10, leg edema type $=2>$ pitting; A11, leg edema location $=3>$ to mid-calf. 
Chart 3 (concluded)

\section{GENERAL INSTRUCTIONS}

A14. Assessment of bioburden

1 Lightly colonized: small amount of serous-type exudate.

2 Heavily colonized: large amount of seropurulent drainage with foul odour and no other cardinal signs of inflammation.

3 Localized infection: large amount of seropurulent drainage with foul odour and either induration, erythema, warmth, or pain.

4 Systemic infection: advancing cellulitis or osteomyelitis

Section B - PATIENT- (PROXY) RATED DOMAINS Read the questions "as they are" to the patient. It is important to qualify that the questions refer to the last 24 hours. If the patient is unable to understand the questions due to cognition or language deficits, section B should not be completed or it may be completed by a proxy only if the proxy knows the patient well and has been with the patient for most of the last 24

hours. The same person should provide proxy information for each assessment; do not complete section B by proxy if the person providing proxy information is not the same.

B1. Pain amount as it relates to the leg ulcer in the last 24 hours. Determine the rating based on a numerical rating scale ranging from $0-10$, then place response in appropriate category.

B2. Pain frequency as it relates to the leg ulcer in the last 24 hours. How often patient experienced pain in the last 24 hours.

B3. Quality of life as it relates to the leg ulcer in the last 24 hours.

After application of the LUMT Portuguese version, the clinical results (part A) indicated the following: 12 (40\%) ulcers with serosanguineous exudate and ten (33.3\%) with serous exudate (33.3); ten (33.3\%) in scant quantity and ten $(33.3 \%)$ in moderate quantity; 15 were (50\%) greater than $10 \mathrm{~cm}^{2} ; 18$ (60\%) with full thickness skin loss; 29 (96.6\%) without edge undermining; $13(46.4 \%)$ with attached type necrotic tissue: white to yellow slough or fibrin; 18 (60\%) with bright beefy red granulation tissue; $18(60 \%)$ with attached, no advancing border of epithelium; 17 (56.6\%) with at least two or three factors affecting periulcer skin viability; 14 (46.7\%) with non-pitting or firmness leg edema and $23(76.6 \%)$ lightly colonized.

In domains evaluated by the patient (part B), nine (30\%) had pain intensity between seven and ten; for 13 (43.3\%), pain was of occasional frequency; and nine (30\%) were satisfied with the ulcer-related quality of life.

In part A (clinically assessed domains), the sum of descriptors generates a score ranging from 0 to 56 . Twenty-three (76.7\%) patients achieved 28 points and none achieved the maximum score. The highest score obtained was 41 and the lowest was 6 . In part B (domains evaluated by the patient), the sum of descriptors generates a score ranging from 0 to 12 . In the domains evaluated by the patient, 18 patients (60\%) did not achieve the highest score nor came close to it. The highest score obtained was 12 and the lowest was 1 . The total sum of the instrument can generate a maximum score of 68 points, and 19 (63.3\%) patients scored between 21 and 40 points. The highest score achieved was 51 and the lowest was 9.

When evaluating the feasibility of the instrument, the $C R$ was $100 \%$, which means total concordance. However, three nurses had difficulty with assessment of item A5 and two nurses with assessment of item A10 of the instrument. Since they had to reread the instructions, more time was required.

\section{DISCUSSION}

The processes of translation and cross-cultural adaptation require not only the literal translation of words, but the respect for the culture of individuals to whom the instrument is intended ${ }^{(21)}$. Translation must be developed by qualified and independent translators ${ }^{(22)}$. The consensual version enables checking inconsistencies and conceptual errors made during translation ${ }^{(18)}$. The native language of translators must be that of the original instrument and they must be fluent in both languages ${ }^{(18)}$. Thus, the steps of translation, synthesis of translations and back-translation were satisfactorily developed and met the recommendations of the literature.

In order to obtain the final version of the instrument, an expert panel must be established for the review and comparison of all translations performed, as well as for modifications and adaptions until achieving an understandable version of the instrument in Brazil $^{(22)}$. In the literature, there is no consensus on the criteria of what makes a professional "an expert", only information that experts/specialists should have clinical experience; publish and research on the topic; understand the conceptual framework involved and have methodological knowledge about the development of instruments ${ }^{(23)}$. In this study, the expert panel consisted of thirteen members who met the above criteria.

In the evaluation of the expert panel, all items presented CVI higher than 0.80 , as recommended in the literature ${ }^{(20)}$. The suggestions made for a better understanding of instruments and equivalence with the Brazilian culture were performed when $70 \%$ of the panel members agreed with the proposal or proposed it.

Regarding the use of LUMT in the pretest, in the clinically evaluated domains, items A3 and A5 stood out. In item A3, half of patients were included in the option of wounds with $10.1 \mathrm{~cm}^{2}$ or more, which represented the worst score. The instrument was created in Canada, where wounds tend to be smaller. In a retrospective study including 554 patients treated from January 2012 to December 2014 at a Canadian wound care clinic, the greatest ulcers had $16 \pm 2 \mathrm{~cm}^{2(24)}$. In item A5, is evaluated the edge undermining, which was not present in 29 out of the 30 wounds evaluated in this study.

In the domains evaluated by the patient, pain intensity is evaluated in item B1, the pain frequency in B2, and the ulcer-related quality of life in item B3. In this study, there was a predominance of individuals with pain intensity between 7 and 10, of occasional frequency and who considered themselves satisfied with the ulcer-related quality of life.

Pain measurement should be part of the assessment of ulcer patients, as it supports the development of strategies for the effective control of ulcers ${ }^{(25)}$. Although most patients in this study did not consider their quality of life as poor, studies associate the presence of wounds with impaired quality of life ${ }^{(26)}$.

Regarding the score obtained through the instrument, most patients did not come close to the maximum score, showing the healing process was not so impaired, because the worst terms describing pain and quality of life were not used.

The profile of nurses who participated in the pretest showed a qualified sample with experience in wounds. The feasibility showed complete concordance. In items A5 and A10, two nurses 
reported difficulty with the evaluation. Item A5 assesses edge undermining, which is uncommon in venous ulcers that tend to be superficial, attached, and predominant among leg ulcers in general ${ }^{(7-8)}$. Item A10 evaluates the advancement of the edge regarding the contraction process towards the center, which is an advanced stage of the healing process. In general, the edge evaluation includes the characteristics of its tissue. The difficulty might be explained by these reasons.

\section{Limitations of the study}

A limitation of the present study was the lack of references on the clinical evaluation of leg ulcers with the LUMT. As this instrument has not been adapted and translated into other languages yet, comparisons of its use in different scenarios are difficult.

\section{Contributions to the area of nursing, health or public policies}

This methodological study contributes to the health area by providing a specific instrument that can be widely used to evaluate leg ulcers and support the planning of therapies adopted in clinical practice. Contributions also include teaching and research, because is described the process of translation and cross-cultural adaptation of instruments, as well as the more accurate comparison of results internationally and the strengthening of homogeneity of collected data.

\section{FINAL CONSIDERATIONS}

The aim of this study was to translate and cross-culturally adapt the Leg Ulcer Measurement Tool (LUMT) to the Portuguese language. After the translation, synthesis of translations and back-translation, the expert panel was assembled and was achieved significant concordance with CVI of 0.97 in the clinical evaluation scale and CVI of 1.00 in the instructions. Adaptations of terms to the Brazilian reality were suggested and the changes were included in the final version with a high level of concordance among experts. The instrument demonstrated content validity, which makes the adaptation appropriate for the Brazilian context.

After the version was approved by the expert panel, a pretest was performed with 30 patients with leg ulcers and ten nurses. The feasibility of the translated and adapted instrument was evaluated and obtained $100 \%$ of concordance rate.

Future studies may enhance the potential use of the instrument. Hence the recommendation to apply the LUMT in Portuguese in different scenarios and evaluate the psychometric measures in order to ensure its clinical validity. The use of instruments subsidizes the standardized collection of good quality data, which reliably demonstrate the changes occurring in patients after the interventions.

\section{FUNDING}

Research conducted with the support of the CNPq - Ministério da Ciência, Tecnologia, Inovações e Comunicação - Brazil.

\section{REFERENCES}

1. Serra R, Butrico L, Ruggiero M, Rossi A, Buffone G, Fugetto F, et al. Epidemiology, diagnosis and treatment of chronic leg ulcers: a systematic review. Acta Phlebol [Internet]. 2015[cited 2018 Nov 26];16:9-18. Available from: https://www.minervamedica. itienijoumalsiactaphlebologicaiarticle.php?cod=R43Y2015N01 A0009

2. Rice JB, Desai U, Cummings AKG, Bimbaum HG, Skomicki M, Parsons N. Burden of venous leg ulcers in the United States. J Med Econ [Internet]. 2014[cited 2018 Nov 26];17(5):347-56. Available from: https://www.ncbi.nlm.nih.gov/pubmed/24625244

3. Rice JB, Desai U, Cummings AKG, Bimbaum HG, Skomicki M, Parsons N. Burden of diabetic foot ulcers for medicare and private insurers. Diabetes Care [Internet]. 2014[cited 2018 Nov 26];37(3):651-58. Available from: https://www.ncbi.nlm.nih.gov/pubmed/24186882

4. Dantas DV, Dantas RAN, Costa IKF, Torres GV. Assistance protocol for venous ulcers patients: validation of contents. Rev Rene [Internet]. 2013[cited 2018 Nov 26];14(3):588-99. Available from: http://www.periodicos.ufc.br/rene/article/view/3497/2739

5. Nunan R, Harding KG, Martin P. Clinical Challenges of chronic wounds: searching for an optimal animal model to recapitulate their complexity. Dis Model Mech [Internet]. 2014[cited 2018 Nov 26];7(11):1205-13. Available from: https://www.ncbi.nlm.nih.gov/pubmed/25359790

6. Marin JA, Woo KY. Clinical Characteristics of Mixed Arteriovenous Leg Ulcers. J Wound Ostomy Continence Nurs [Internet]. 2017[cited 2018 Nov 26];44(1):41-7. Available from: https://www.ncbi.nlm.nih.gov/pubmed/28060003

7. O'Connor S, Murphy S. Chronic venous leg ulcers: is topical zinc the answer? A review of the literature. Adv Skin Wound Care [Internet]. 2014[cited 2018 Nov 26];27(1):35-44. Available from: http://insights.ovid.cornipubmed?pmid=24343392

8. Dantas DV, Torres GDV, Salvetti MDG, Costa IKF, Dantas RAN, Araújo RDO. Clinic validation protocol for venous ulcers in high complexity. Rev Gaúcha Enferm [Internet]. 2016[cited 2018 Nov 26];37(4):e59502. Available from: http://dx.doi.org/10.1590/1983- 1447.2016.04.59502

9. Shan GQ, Zhang YN, Ma J, Li YH, Zuo DM, Qiu JL, et al. Evaluation of the effects of homologous platelet gel on healing lower extremity wounds in patients with diabetes. Int J Low Extrem Wounds [Internet]. 2013[cited 2018 Nov 25];12(1):22-9. Available from: http://journals. sagepub.com/doi/pdf/10.1177/1534734613477113

10. Arisandi $D$, Oe M, Roselyne YR, Matsumoto M, Oqai K, Nakagami G, et al. Evaluation of validity of the new diabetic foot ulcer assessment scale in Indonesia. Wound Repair Regen [Internet]. 2016[cited 2018 Nov 25];24(5):876-84. Available from: https://www.ncbi.nlm.nih.gov/ pubmed/27400025

11. Dissemond J. Chronic leg ulcers. Hautartz [Internet]. 2017[cited 2018 Nov 25]; 68(8):614-20. Available from: https://link.springer.comiarticle/ 10.1007\%2Fs00105-017-4010-8 
12. Torres SMDSSO, Araújo ROE, Costa IKF, Tibúrcio MP, Sousa AJG, Pergola-Marconato AM, et al. Health-related quality of life in patients with venous leg ulcer treated in primary care in Brazil and Portugal. PloS One [Internet]. 2018[cited 2018 Nov 25];13(4):e0195990. Available from: https://www.ncbi.nlm.nih.gov/pubmed/29689069

13. Arndt JV, Kelechi TJ. An overview of instruments for wound and skin assessment and healing. J Wound Ostomy Continence Nurs [Internet]. 2014[cited 2018 Nov 25];41(1):17-23. Available from: https://www.ncbi.nlm.nih.gov/pubmed/24378690

14. Choi EP, Chin WY, Wan EY, Lam CL. Evaluation of the internal and external responsiveness of the Pressure Ulcer Scale for Healing (PUSH) tool for assessing acute and chronic wounds. J Adv Nurs[Internet]. 2016 [cited 2018 Nov 25];72(5):1134-43. Available from: https://www.ncbi. nlm.nih.gov/pubmed/26750541

15. George-Saintilus E, Tommasulo B, Cal CE, et al. Pressure ulcer PUSH score and traditional nursing assessment in nursing home residents: do they correlate? J Am Med Dir Assoc [Internet]. 2009 [cited 2019 May 07];10(2):141-14419187884. Available from: https://www.sciencedirect. com/science/article/pii/S1525861008004167

16. Oliveira BGRB, Silva JA, Silveira IA et al. Instrumentos de avaliação clínica para úlceras de perna. Rev Enf Atual InDerme [Internet]. 2019 [cited 2019 May 07];Especial(2019);87. Available from: https://revistaenfermagematual.com.br/index.php/revista/article/view/171

17. Woodbury MG, Houghton PE, Campbell KE, Keast DH. Development, validity, reliability, and responsiveness of a new leg ulcer measurement tool. Adv Skin Wound Care [Internet]. 2004 [cited 2018 Nov 25];17(4):187-96. Available from: https://www.ncbi.nlm.nih.gov/ pubmed/15360028.

18. Guillemin F, Bombardier C, Beaton D. Cross-cultural adaptation of health-related quality of life measures: literature review and proposed guidelines. J Clin Epidemiol [Internet]. 1993[cited 2018 Nov 25];46(12):1417-32. Available from: https://www.ncbi.nlm.nih.gov/ pubmed/8263569

19. Alves DFS, Almeida AO, Silva JLG, Morais Fl, Dantas SRPE, Alexandre NMC. Translation and adaptation of the Bates-Jensen wound assessment tool for the Brazilian culture. Texto Contexto Enferm [Internet]. 2015[cited 2018 Nov 25];24(3):826-33. Available from: http:// www.scielo.br/pdfitce/v24n3/0104-0707-tce-24-03-00826.pdf

20. Coluci MZO, Alexandre NMC, Milani D. Construção de instrumentos de medida na área da saúde. Ciênc Saúde Colet [Internet]. 2015[cited 2018 Nov 25];20(3):925-36. Available from: http://www.scielo.bripdf/csc/v20n3/1413-8123-csc-20-03-00925.pdf

21. Jensen R, Cruz DALM, Tesoro MG, Lopes MHBM. [Translation and cultural adaptation for Brazil of the Developing Nurses'Thinking model]. Rev Latino-Am Enfermagem [Internet]. 2014 [cited 2017 Dec 16];22(2):197-203. Available from: http://www.scielo.br/pdf/rlae/v22n2/ pt_0104-1169-rlae-22-02-00197.pdf Portuguese.

22. Souza DP, Orlandi FS. Tradução e adaptação cultural da Patient Perceptions of Hemodialysis Scaleno Brasil. Rev Bras Enferm [Internet]. 2019 [cited 2019 May 07];72(2):331-7. Available from: http://dx.doi.org/10.1590/0034-7167-2018-0052

23. Alexandre NMC, Coluci MZO. Validade de conteúdo nos processos de construção e adaptação de instrumentos de medida. Ciênc Saúde Colet[Internet]. 2011 [cited 2018 Nov 25];16(7):3061-8. Available from: http://www.redalyc.org/articulo.oa?id=63019107006

24. Yang GK, Cao S, Kayssi A, et al. Critical evaluation of delayed healing of venous leg ulcers: a retrospective analysis in Canadian Patients. Am J Clin Dermatol [Internet]. 2016 [cited 2019 May 07];17(5):539-44. Available from: https://doi.org/10.1007/s40257-016-0214-4

25. Cooper RA, Bjarnsholt T, Alhede M. Biofilms in wounds: a review of present knowledge. J Wound Care [Internet]. 2014[cited 2018 Nov 25];23(11):570-82. Available from: https://www.ncbi.nlm.nih.gov/pubmed/25375405

26. Silveira IA, Oliveira BGRB, Oliveira AP, Andrade NC. Pain pattern in patients with leg ulcers. Rev Enf UFPE[Internet]. 2017[cited 2018 Nov 25];11(2):617-24. Available from: https://periodicos.ufpe.br/revistas/revistaenfermagem/article/view/11981/14537 